\title{
Assessment of CSR Performances in Some Selected Commercial Banks in Bangladesh
}

\section{Md. Abul Kalam Azad ${ }^{1}$, Mohammad Zahir Raihan², Mohammad Zahid Hossain Bhuiyan $^{3}$}

${ }^{1}$ Assistant Professor of Finance, IIUC, Bangladesh

${ }^{2}$ Associate Professor (Finance), School of Business, Bangladesh Open University, Bangladesh

${ }^{3}$ Assistant Professor of Management, IIUC, Bangladesh

\begin{abstract}
The study is on 10 locally private commercial banks operating in Bangladesh. In this study, secondary data have been extensively used. Some primary data have also been used in the study. These were collected from a total number of 10 Executives in-charge of Corporate Social Responsibility Department using structured closed end questionnaire. While collecting primary data, direct interview method was mainly used. The main objective of the study is to critically analyse the CRS performances in the selected banks which covered the Heads of CSR activities, the determinants of CSR activities, Investment in CSR activities and Impact of CSR investment. The period of empirical study covered 4 financial years ranging from 2009 to 2012. The main findings of the study are; (i) some $90 \%$ of the respondents have emphasized on the significance of CSR activities in the selected banks, (ii) some $60 \%$ of the respondents have emphasized on the significant impact of CSR investment on the Market price of the Share (MPS), (iii) the major factors affecting CSR activities have been Sustainable development, Business tool, Leadership and ethics, (iv) empirical analysis of the study reveals that the CSR investments as percentage of total investment of the respective banks have been very negligible ranging from $0.01 \%$ to $2.87 \%$ only during the study period. It is found that out of the seven heads of CSR expenditures Health sector have occupied the highest position in majority banks followed by Education sector. Therefore, it can be concluded that the selected banks should increase their investment in CSR activities in order to create more confidence among the existing clients as well as prospective customer in one hand and increase MPS of the banks on the other.
\end{abstract}

Key Words: CSR, Sustainable Development, Corporate Governance, Corporate ethics

JEL Classification Code: G21; G28 


\section{INTRODUCTION}

Corporate Social Responsibility (CSR) is also known by a number of other names. These include corporate responsibility, corporate accountability, corporate ethics, corporate citizenship or stewardship, responsible entrepreneurship, and "triple bottom line," to name just a few. As CSR issues become increasingly integrated into modern business practices, there is a trend towards referring to it as "responsible competitiveness" or "corporate sustainability" (Mackey \&Tyson, 2007). Though CSR is an evolving concept, but currently it does not have a universally accepted definition. Generally, CSR is understood to be the way firms integrate social, environmental and economic concerns into their values, culture, decision making, strategy and operations in a transparent and accountable manner and thereby establish better practices within the firm, create wealth and improve society. As issues of sustainable development become more important, the question of how the business sector addresses them is also becoming an element of CSR. Leonardo, Rocco and Hasan (2007) have found that businesses play a pivotal role both in job and wealth creation in society and in the efficient use of natural capital, CSR is a central management concern. It positions companies to both proactively manage risks and take advantage of opportunities, especially with respect to their corporate reputation and the broad engagement of stakeholders. The latter can include shareholders, employees, customers, communities, suppliers, governments, non-governmental organizations, international organizations and others affected by a company's activities.

\section{RATIONALE OF THE STUDY}

Successful executives know that their long-term success is based on continued good relations with a wide range of individuals, groups and institutions. Smart firms know that business can't succeed in societies that are failing-whether this is due to social or environmental challenges, or governance problems. Moreover, the general public has high expectations of the private sector in terms of responsible behaviour. Consumers expect goods and services to reflect socially and environmentally responsible business behaviour at competitive prices.

Shareholders, nowadays, are searching for enhanced financial performance that integrates social and environmental considerations, both in terms of risk and opportunities. Governments, too, are becoming aware of the national competitive advantages to be won from a responsible business sector. At the same time, leading industry associations, such as the World Business Council for Sustainable Development, have also suggested that countries as well as companies might gain a competitive advantage from corporate social responsibility. Even companies which may have a good reputation can risk losing their hard-earned name when they fail to put systematic approaches in place to ensure continued positive performance. These firms frequently expend considerable time and money attempting to regain their reputation, with mixed results.

It is also important to acknowledge that while positive or neutral correlations between social and environmental responsibility and superior financial performance have generally been supported by the evidence, conclusive causal links have not. Many studies are being undertaken, with varying conclusions.

The aforesaid discussions especially the benefits derived by the firms by practicing CSR and the improvement in their financial performances from CSR expenditures have created interest to make an in-depth study on assessment of CSR performances in some selected commercial banks in Bangladesh. 


\section{OBJectives}

The main objective of the study is to critically analyse the CSR performances in the selected banks operating in Bangladesh. The specific objectives are listed below;

- To evaluate the extent of investments made in CSR activities in case of the selected banks.

- To examine the impact of CSR investment on the financial performance of the sample banks leading to the shareholders wealth.

\section{HYPOTHESIS}

Based on the above objectives, the two hypotheses we tested here are; $\mathrm{H}_{01}$ : There is no impact of CSR investment on the market price of share $\mathrm{H}_{\mathrm{a} 1}$ : There is impact of CSR investments on the market price of share

\section{Methodology}

The detailed methodology of the study is discussed as follows;

Sample selection: Out of total 47 banks currently operating in Bangladesh, only privately commercial banks are in the population for this study numbering 30. Public commercial banks, foreign banks and investment banks did not take into account due to their difference in operation and government attitude. Out of 30 banks only 10 banks are selected for the study which presents around 33\% of the total population. The reason behind such selection is only these 10 banks have been investing on CSR for last 4 years continuously according to Bangladesh Bank Report on CSR on July, 2011. The names of the selected banks are Eastern Bank Limited (EBL), Bank Asia Limited (BAL), Dutch Bangla Bank Limited (DBBL), Jamuna Bank Limited (JBL), Pubali Bank Limited (PuBL), Premier Bank Limited (PrBL), Uttara Bank Limited (UBL), Trust bank Limited (TBL) and Mercantile Bank Limited (MBL).

Primary Data: An opinion survey was conducted as regards the factors affecting CSR performances in the banks. Chief of CSR Department was selected as respondent. A Questionnaire was developed using closed end questions. Five scales Likert scale was also used in questionnaire to gather opinions of the respondents.

Secondary Data: In line with the research objectives, quantitative data were collected from Bangladesh Bank Report July 2011 on CSR performances. In order to get the market value of the selected banks, www.dscbd.org is used following the day price before record date over four years. In order to develop the basic theory and background of the relevant topic a list of indexed journal is used along with newspaper, Bangladesh Bank publications, periodic and others.

Data Analysis: Basic frequency table is used as Statistical Package for the Social Sciences (version 20). Moreover, multiple regressions model and Zero order correlation matrix were mainly used to examine the impact of CSR investments. In order to test null hypothesis, T-test, F-test and ANOVA were also used in the study.

\section{LITERATURE REVIEW}

The general signalling role of CSR was also studied by Goyal (2006). That study however is considerably different from the relative authors as it did not consider the brand-value of firms. Rather, Goyal (2006) investigated the signaling role of CSR when firms considering FDI are interested in favorable terms. Our study is similar to Goyal (2006) in that we also 
use the well-established signaling theory (c.f. Spence 1974, Riley 2001, Vega-Redondo 2003, Gibbons 1992) to perform our analysis.

Theoretical studies linking CSR and financial performance are few both nationally and internationally. Siegel and Vitaliano (2007) provide an excellent review, and here we highlight some of their observations. In the seminal pieces (c.f. Baron 2001, McWilliams and Siegel 2001), CSR was linked to profit-maximization by modeling firms' products to contain "social" attributes competing for socially responsible customers. In other words, firms are responding to a demand for CSR. Other studies highlight the role of asymmetric information. In particular, in exercising CSR, firms can signal to consumers that in being 'good,' perhaps even reliable and honest, they will produce better products.

Barnea \& Rubin (2005) depict that in recent years firms have greatly increased the amount of resources allocated to activities classified as Corporate Social Responsibility (CSR). This increase in CSR expenditure may be consistent with firm value maximization if it is solely a response to changes in stakeholders' preferences. We find that insiders' ownership and leverage are negatively related to the social rating of firms, while institutional ownership is uncorrelated with it. These results support our hypothesis that affiliated shareholders induce firms to over-invest in CSR when they don't bear much of the cost associated with it.

Leonardo, Rocco \& Hasan (2007) found CSR is increasingly a core component of corporate strategy in the global economy. In recent years its importance has become even greater, primarily because of the financial scandals, investors' losses, and reputational damage to listed companies. The paper highlights two main findings: a significant upward trend in absolute value abnormal returns, irrespective of the type of event (for example, addition or deletion from the index), and a significant negative effect on abnormal returns after exit announcements from the Domini index. The latter effect persists even after controlling for concurring financial distress shocks and stock market seasonality.

Mackey \&Tyson (2007) addressed the debate about whether firms should engage in socially responsible behavior by proposing a theoretical model in which the supply of and demand for socially responsible investment opportunities determine whether these activities will improve, reduce, or have no impact on a firm's market value. The theory shows that managers in publicly traded firms might fund socially responsible activities that do not maximize the present value of their firm's future cash flows yet still maximize the market value of the firm. Using a sample of non-financial Brazilian companies from 2005 to 2007, they analyses whether corporate social responsibility (CSR) has an impact on firm value. Using companies' Tobin's $Q$ as a proxy for their market value, the paper finds that firms that compose the Bovespa Corporate Sustainability Index (ISE) are traded at a premium compared to the other publicly traded firms. They also indicate that the positive impact of these policies is independent of the econometric method and period analyzed. The results confirm that the benefits of corporate social responsibility policies surpass the possible costs implied by the adoption of such policies, leading corporate social responsibility to exert a positive impact on firm value.

Prior empirical research has reported mixed results. McWilliams and Siegel (2000) provide an excellent review and we report their main observation. One stream has used event-study methods to assess the short-run impact of CSR (c.f. Clinebell and Clinebell, 1994; Hannon and Milkovich, 1996; Posnikoff, 1997; Teoh, Welch and Wazzan, 1999; Worrell, Davidson, and Sharma, 1991; Wright and Ferris, 1997). Another stream highlighted the long-term effects of CSR (c.f. Aupperle, Carroll and Hatfield, 1985; McGuire, Sundgren and Schneewies, 1988). 
McWilliams and Siegel $(1997,2000)$ have indicated how methodological issues can affect the findings and may be used to resolve some of the differences.

\section{ANALYSIS AND FINDINGS}

\section{Analyses of respondents' Opinion Survey:}

Table 01 (Appendix) represents the importance of CSR in the selected banks. It is revealed that $40 \%$ respondents have opined in favour of very importance of CSR activities, 30\% respondents have opined in favour more than importance, $20 \%$ of respondents opined for average importance and only $10 \%$ respondents responded for less than importance. Thus, it can be said that the overwhelming majority of the respondents $(90 \%)$ have emphasized on the significance of CSR activities in the selected banks.

Table 02 (Appendix) represents the impact of CSR activities on the performance of the bank. It is seen that $10 \%$ respondents have opined in favour of CSR activities having more than average impact on bank performance, $40 \%$ respondents have opined in favour average impact on bank performance, another $40 \%$ respondents have opined in favour less impact and only $10 \%$ respondents have opined for not any impact of CSR activities on the performance of the selected banks. Thus, it reveals that the fifty percent of the respondents have emphasized the significance of CSR activities on the bank performance in the selected banks.

Table 03 represents the impact of CSR activities on the market price of the bank. It is seen that, $30 \%$ respondents have opined in favour of CSR activities have more than impact on MPS, 30\% respondents have opined in favour average impact on MPS, and another $40 \%$ respondents have opined in favour less than impact effect on MPS. Thus, it reveals that the majority $(60 \%)$ of the respondents have emphasized on the significant impact of CSR investment on the MPS in the selected banks.

Table 04 (Appendix) reveals the importance of the given factors in terms of weighted average score (WAS). Among the factors of CSR activities, Sustainable development occupies the first with WAS of 7.00 followed by Business tool with WAS of 6.30, Leadership with WAS of 5.20, Globalization with WAS of 4.70, Governance with WAS of 4.40, Corporate sector impact with WAS of 3.10, Finance with WAS of 2.30 and lastly Communication WAS of 1.70. Thus, it reveals that, Sustainable development, Business tool, leadership and ethics are the main concern for taking CSR activities as important for the selected banks.

Table 05 (Appendix) presents the extent of the present CSR investments by the banks from the range not at all adequate to highly adequate scale. Among the factors, Globalization ranks first with WAS of 3.10, followed by Business tool, Ethics, Corporate sector impact, Finance, Governance, Leadership, Communication and sustainable development with WAS of 2.90, 2.80, 2.70, 2.60, 2.50, 2.40, 2.00 and 1.90 respectively. Compared to table 05, this table reveals that even though the respondents have marked sustainable development as first reason for CSR investment but in comparison to the importance the investment is highly inadequate. Thus, it can be said that the present investments of the banks is significantly inadequate by the banks for all the factors that considered as important for the selected bank's CSR activities.

\section{Analysis and findings from the empirical data:}

It is seen from the table 06 (Appendix) that the percentage of investment in CSR activities compared to total investment in all the banks have been highly negligible ranging from $0.01 \%$ to $2.87 \%$ only. However, throughout the study period, the CSR investments had shown an increasing trend in MBL. A slightly negative trend was observed in case of DBBL and the rest of the banks had no trend in terms of investment in CSR activities. 
The analysis of table 07 (Appendix) reveals that of the 10 selected banks, DBBL ranks first regarding average CSR expenditures during 2009 to 2012, the yearly average CSR expenditures being TK $134.57 \mathrm{~m}$. followed by MBL, the yearly average expenditure being TK $32.15 \mathrm{~m}, \mathrm{PuBL}$, the yearly average expenditure being TK $30.09 \mathrm{~m}$, TBL, the yearly average expenditure being TK $26.34 \mathrm{~m}$, DBL, the yearly average expenditure being TK $22.67 \mathrm{~m}$, PrBL, the yearly average expenditure being TK $21.19 \mathrm{~m}$, UBL, the yearly average expenditure being TK $20.50 \mathrm{~m}$, BAL, the yearly average expenditure being TK $15.57 \mathrm{~m}$, EBL, the yearly average expenditure being TK $12.14 \mathrm{~m}$ and lastly JBL with yearly average expenditure being TK $9.31 \mathrm{~m}$ only. These figures imply the importance of CSR expenditures emphasized by the selected bankers during the selected period.

Again, it is found that of the seven heads of CSR expenditure Health sector occupies the highest position in cases of EBL, DBBL, PrBL, PuBL,UBL and MBL followed by Education sector. In case of DBL, BAL, TBL and JBL, Education sector occupies the highest position followed by Health sector. All the statistics signify that Health and Education sector have been given the priority by all the selected banks while incurring CSR expenditures. Moreover, analysing the CV values, it is revealed that the CSR expenditures on the heads Education, Sports, Art and Culture, Environment have been more consistent than the heads Health, Disasters \& Relief and Others across the study period in case of EBL. In case of BAL, CSR expenditure on the heads Education, Sports have been more consistent than the rest across the study period, In case of DBBL, DBL and PuBL, CSR expenditures on all the heads remain inconsistent during the study periods. In case of JBL, CSR expenditures on Disaster \& Relied remain consistent only than other heads. In case of PrBL, CSR expenditure on the heads Education, Art and Culture, Environment have been more consistent than the heads Health, Sports, Disasters \& Relief and Others across the study period. In case of UBL, CSR expenditure remains consistent on all the head other than Education during the study period. In case of TBL, CSR expenditure on all CSR Heads remain inconsistent during the study period other than Disaster and relief. And lastly, in case of MBL, CSR expenditures on the heads Health, Disasters \& Relief, Art and Culture and Environment have been more consistent than the heads Education, Sports, and Others across the study period. Before examining the impact of investment in CSR activities on the market price of the share of the selected banks, first of all, we are to examine the relationship between CSR activities and Market price per share. Such relationship has been determined on the basis of coefficient of correlation between market price per share (MPS) and investment in Education, MPS and investment in Health, MPS and investment in Sports, MPS and investment in Disaster relief, MPS and investment in Art and culture, MPS and investment in Environment and MPS and investment in others. Table (08) (Appendix) shows the coefficient of correlation ( $\mathrm{r}$ ) between these variables. It is seen from the table that $r$ between (MPS) and Education, MPS and investment in Health, MPS and investment in Sports, MPS and investment in Disaster relief, MPS and investment in Art and culture, MPS and investment in Environment and MPS and investment in others have been calculated 0.356, 0.348,0.260,0.233, 0.301, 0.354 and 0.357 respectively. Such values of (r) signify that there exists positive correlation between these variables. All these values have been significant at $1-5 \%$ level of significance. Therefore, it can be said that all the independent variables have positive correlation with the dependent variable MPS. Therefore, it is seen that the null hypothesis; There is no relationship between investment in CSR activities and market price of share has been rejected. This implies that investment in CSR activities have relationship with MPS. 


\section{CONCLUSION}

The study concludes that investment in CSR activities in the selected banks have positive impact on the MPS of the banks thereby leading to shareholders' wealth. But, it is found in the study that CSR investments as percentage of total investment of the respective banks have been very meagre during the study period. But, it is the demand of the age that more and more investments need to be made in all the organizations especially in the banks, the service rendering industry for the fulfilment of CSR of the organization. It is true that CSR activities lead to sustainable growth and development of the organizations, fulfilling CSR towards the nation also. Therefore, the respective banks authority as well the Bangladesh Bank (BB) authority, as the supervisory bank has a great role to play in order to increase the investment ceiling of the banks in CSR activities. Moreover, strict supervision of BB is a must in order to see whether the Private commercial banks and National commercial banks are implementing the guidelines of BB issues for time to time as regards CSR activities.

\section{REFERENCES}

[1] Aupperle, Carroll and Hatfield J 1985, “An Empirical Examination of the Relationship Between Corporate Social Responsibility and Profitability," Academy of Management Journal, 28(2), pp. 446-463

[2] Barnea A and Rubin A 2005, Corporate Social Responsibility as a Conflict between Shareholders, Social Sciences and Humanities Research Council of Canada, pp. 13

[3] Baron D 2001, "Private Politics, Corporate Social Responsibility and Integrated Strategy," Journal of Economics and Management Strategy, 10, pp. 7-45

[4] Clinebell SK and Clinebell JM 1994, "The Effect of Advanced Notice of Plant Closing on Firm Value," Journal of Management, 20, pp. 553-564

[5] Goyal A 2006, "Corporate Social Responsibility as a Signaling Device for FDI," Internal Journal of the Economics of Business, 3(4), pp. 54-72

[6] Hannon J and Milkovich G 1996, "The Effect of Human Resource Reputation Signals on Share Prices: An event study," Human Resource Management, 35(3) pp. 405-424

[7] Leonardo B, Rocco C and Hasan I 2007, Corporate Social Responsibility and Shareholder's Value: An Event Study Analysis, Working Paper 2007-6, Federal Reserve Bank of Atlanta

[8] Mackey A \&Tyson M 2007, Corporate social responsibility and Firm performance: investor Preferences and corporate strategies, Academy of Management Review, 32 (3), 817-835

[9] McGuire JA, Sundgren and Schneeweis T 1988, "Corporate Social Responsibility and Firm Financial Performance," Academy of Management Journal, 31(4), pp. 854-872

[10] McWilliams A, and Siegel D2000, "Corporate Social Responsibility and Financial Performance: Correlation or Misspecification?" Strategic Management Journal, 21, pp. 603-609

[11] McWilliams A, and Siegel D 2001, “Corporate Social Responsibility: A Theory of the Firm Perspective," Academy of Management Review, 26, pp.117-127

[12] Siegel D and Vitaliano D 2007, “An Empirical Analysis of the Strategic Use of Corporate Social Responsibility," Journal of Economics and Management Strategy, 16(3), pp. 773-792

[13] Teoh SH, Welch L and Wazzan CP 1999, "The Effect of Socially Activist Investment Policies on the Financial Markets: Evidence from the South African boycott," Journal of Business, 72(1), pp. 35-89

[14] Worrell D, Davidson WN and Sharma VN 1999, "Layoff announcements and stockholder wealth," Academy of Management Journal, 34(3), pp. 662 


\section{Appendix:}

Table 01: Response in Opinion survey for the Importance of CSR

\begin{tabular}{|ll|l|l|l|l|}
\hline & Frequency & Percent & $\begin{array}{l}\text { Valid } \\
\text { Percent }\end{array}$ & $\begin{array}{l}\text { Cumulative } \\
\text { Percent }\end{array}$ \\
\hline Valid & Less than important & 1 & 10.0 & 10.0 & 10.0 \\
& Average important & 2 & 20.0 & 20.0 & 30.0 \\
More than important & 3 & 30.0 & 30.0 & 60.0 \\
very important & 4 & 40.0 & 40.0 & 100.0 \\
Total & 10 & 100.0 & 100.0 & \\
\hline
\end{tabular}

Table 02: Response in Opinion survey for the Impact of CSR

\begin{tabular}{|c|c|c|c|c|c|}
\hline & & Frequency & Percent & $\begin{array}{l}\text { Valid } \\
\text { Percent }\end{array}$ & $\begin{array}{l}\text { Cumulative } \\
\text { Percent }\end{array}$ \\
\hline \multirow[t]{5}{*}{ Valid } & Not any impact & 1 & 10.0 & 10.0 & 10.0 \\
\hline & Less impact & 4 & 40.0 & 40.0 & 50.0 \\
\hline & Average impact & 4 & 40.0 & 40.0 & 90.0 \\
\hline & More than average impact & 1 & 10.0 & 10.0 & 100.0 \\
\hline & Total & 10 & 100.0 & 100.0 & \\
\hline
\end{tabular}

Table 03: Response in Opinion survey for the influence to Market price of share for CSR investment

\begin{tabular}{|c|c|c|c|c|c|}
\hline & & Frequency & Percent & $\begin{array}{l}\text { Valid } \\
\text { Percent }\end{array}$ & $\begin{array}{l}\text { Cumulative } \\
\text { Percent }\end{array}$ \\
\hline \multirow[t]{4}{*}{ Valid } & Less than important & 4 & 40.0 & 40.0 & 40.0 \\
\hline & Average important & 3 & 30.0 & 30.0 & 70.0 \\
\hline & More than important & 3 & 30.0 & 30.0 & 100.0 \\
\hline & Total & 10 & 100.0 & 100.0 & \\
\hline
\end{tabular}

Table 04: Factors that affect CSR activities in the selected banks

\begin{tabular}{|l|c|c|c|c|c|c|c|c|c|c|c|}
\hline Factors for CSR activities & $\begin{array}{c}\text { 1=Not at all } \\
\text { important }\end{array}$ & 2 & 3 & 4 & 5 & 6 & 7 & 8 & $\begin{array}{c}\text { 9=Highly } \\
\text { Important }\end{array}$ & WAS & Rank \\
\hline Sustainable Development & & & & & & 3 & 5 & 1 & 1 & 7.00 & 1 st \\
\hline Globalization & & & 2 & 3 & 1 & 4 & & & & 4.70 & 5 th \\
\hline Governance & & & 2 & 3 & 4 & 1 & & & & 4.40 & 6 th \\
\hline Corporate sector impact & & 4 & 3 & 2 & & 1 & & & & 3.10 & 7 th \\
\hline Communications & 4 & 5 & 1 & & & & & & & 1.70 & 9 th \\
\hline Finance & 4 & 3 & 1 & & 2 & & & & & 2.30 & 8 th \\
\hline Ethics & & & & 3 & 5 & 1 & 1 & & & 5.00 & 4 th \\
\hline Leadership & & & & 3 & 2 & 5 & & & & 5.20 & 3 rd \\
\hline Business Tool & & & & 1 & 1 & 4 & 2 & 2 & & 6.30 & 2nd \\
\hline
\end{tabular}

WAS $=$ weighted Average Score 
Table 05: Present investment in CSR activities by the bank over 2009 to 2012

\begin{tabular}{|l|c|c|c|c|c|c|c|}
\hline Factor & $\begin{array}{c}\text { Not at all } \\
\text { Adequate }\end{array}$ & $\begin{array}{c}\text { Inade } \\
\text { quate }\end{array}$ & $\begin{array}{c}\text { Less than } \\
\text { Adequate }\end{array}$ & $\begin{array}{c}\text { Only } \\
\text { Adequate }\end{array}$ & $\begin{array}{c}\text { Highly } \\
\text { Adequate }\end{array}$ & WAS & Rank \\
\hline Sustainable Development & 5 & 2 & 2 & 1 & & 1.90 & 9th \\
\hline Globalization & & 4 & 2 & 3 & 1 & 3.10 & 1 st \\
\hline Governance & 1 & 5 & 2 & 2 & & 2.50 & 6th \\
\hline Corporate sector impact & 1 & 4 & 3 & 1 & 1 & 2.70 & 4 th \\
\hline Communications & 3 & 5 & 1 & 1 & & 2.00 & 8th \\
\hline Finance & 2 & 4 & 1 & 2 & 1 & 2.60 & 5 th \\
\hline Ethics & 1 & 3 & 4 & 1 & 1 & 2.80 & 3 rd \\
\hline Leadership & 5 & & 2 & 2 & 1 & 2.40 & 7 th \\
\hline Business Tool & & 4 & 3 & 3 & & 2.90 & 2nd \\
\hline
\end{tabular}

WAS= weighted Average Score

Source: Opinion survey

Table 06: Percentage of investment in CSR activities out of total investments in the selected banks during 2009 to 2012 (amount in Million TK)

\begin{tabular}{|c|c|c|c|c|c|c|c|c|c|c|c|c|}
\hline \multirow{3}{*}{ Bank } & $\begin{array}{c}\text { Invest } \\
\text { ment in } \\
\text { CSR ac } \\
\text { tivities }\end{array}$ & $\begin{array}{c}\text { Total } \\
\text { invest } \\
\text { ment } \\
\text { of the } \\
\text { bank }\end{array}$ & $\begin{array}{c}\text { \% of } \\
\text { total } \\
\text { invest } \\
\text { ment }\end{array}$ & $\begin{array}{c}\text { Invest } \\
\text { ment in } \\
\text { CSR ac } \\
\text { tivities }\end{array}$ & $\begin{array}{c}\text { Total } \\
\text { invest } \\
\text { ment } \\
\text { of the } \\
\text { bank }\end{array}$ & $\begin{array}{c}\% \text { of } \\
\text { total } \\
\text { invest } \\
\text { ment }\end{array}$ & $\begin{array}{c}\text { Invest } \\
\text { ment in } \\
\text { CSR ac } \\
\text { tivities }\end{array}$ & $\begin{array}{c}\text { Total } \\
\text { Invest } \\
\text { ment } \\
\text { of the } \\
\text { bank }\end{array}$ & $\begin{array}{c}\% \text { of } \\
\text { total } \\
\text { invest } \\
\text { ment }\end{array}$ & $\begin{array}{c}\text { Invest } \\
\text { ment in } \\
\text { CSR ac } \\
\text { tivities }\end{array}$ & $\begin{array}{c}\text { Total } \\
\text { invest } \\
\text { ment } \\
\text { of the } \\
\text { bank }\end{array}$ & $\begin{array}{c}\% \text { of } \\
\text { invest } \\
\text { ment }\end{array}$ \\
\hline EBL & 9.50 & 5,896 & 0.16 & 1.00 & 5,325 & 0.02 & 6.74 & 8,806 & 0.08 & 31.32 & 9,827 & 0.32 \\
\hline BAL & 13.82 & 4,211 & 0.33 & 6.92 & 6,134 & 0.11 & 1.00 & 9,663 & 0.01 & 40.55 & 12076 & 0.34 \\
\hline DBBL & 39.21 & 5,909 & 0.66 & 171.02 & 5,955 & 2.87 & 159.21 & 9,670 & 1.65 & 168.86 & 11002 & 1.53 \\
\hline JBL & 14.22 & 4,390 & 0.32 & 1.45 & 5,390 & 0.03 & 4.58 & 8,503 & 0.05 & 17.00 & 10891 & 0.16 \\
\hline PuBL & 27.49 & 5,557 & 0.49 & 24.49 & 8,376 & 0.29 & 18.88 & 12,168 & 0.16 & 49.51 & 16516 & 0.30 \\
\hline PrBL & 8.40 & 3,461 & 0.24 & 7.51 & 4,107 & 0.18 & 11.57 & 6,513 & 0.18 & 57.30 & 10195 & 0.56 \\
\hline UBL & 10.00 & 14456 & 0.07 & 8.90 & 11,186 & 0.08 & 3.08 & 22,502 & 0.01 & 60.00 & 18591 & 0.32 \\
\hline TBL & 9.52 & 3,785 & 0.25 & 1.00 & 4,963 & 0.02 & 46.75 & 8,705 & $0.54 \%$ & 48.10 & 8,529 & 0.56 \\
\hline DBL & 14.62 & 5,972 & 0.24 & 12.17 & 7,239 & 0.17 & 9.28 & 8,660 & 0.11 & 92.53 & 8,443 & 1.10 \\
\hline MBL & 9.40 & 7,100 & 0.13 & 22.40 & 7,690 & 0.29 & 22.93 & 9,673 & 0.24 & 36.04 & 10937 & 0.33 \\
\hline
\end{tabular}

Source: Activity report of the Financial Institution 2009, and 2012.

Table07: Descriptive Table of the CSR activities by the selected bank over the study period

\begin{tabular}{|l|l|l|l|l|}
\hline Name of the Bank & Head & Mean & SD & CV \\
\hline \multirow{5}{*}{ Eastern Bank Limited } & Education & 2.19 & 2.77 & 0.791 \\
\cline { 2 - 5 } & Health & 5.45 & 5.05 & 1.079 \\
\cline { 2 - 5 } & Sports & 0.99 & 1.07 & 0.925 \\
\cline { 2 - 5 } & Disaster relief & 0.50 & 0.30 & 1.653 \\
\cline { 2 - 5 } & Art \& Culture & 1.42 & 1.57 & 0.907 \\
\cline { 2 - 5 } & Environment & 1.10 & 1.11 & 0.986 \\
\cline { 2 - 5 } & Others & 0.49 & 0.48 & 1.011 \\
\cline { 2 - 5 } & total & 12.14 & & \\
\hline \multirow{5}{*}{ Bank Asia Limited. } & Education & 5.35 & 6.82 & 0.785 \\
\cline { 2 - 5 } & Health & 4.56 & 3.65 & 1.249 \\
\cline { 2 - 5 } & Sports & 2.59 & 2.99 & 0.866 \\
\cline { 2 - 5 } & Disaster relief & 0.54 & 0.34 & 1.586 \\
\cline { 2 - 5 } & Art \& Culture & 1.41 & 1.03 & 1.364 \\
\hline
\end{tabular}




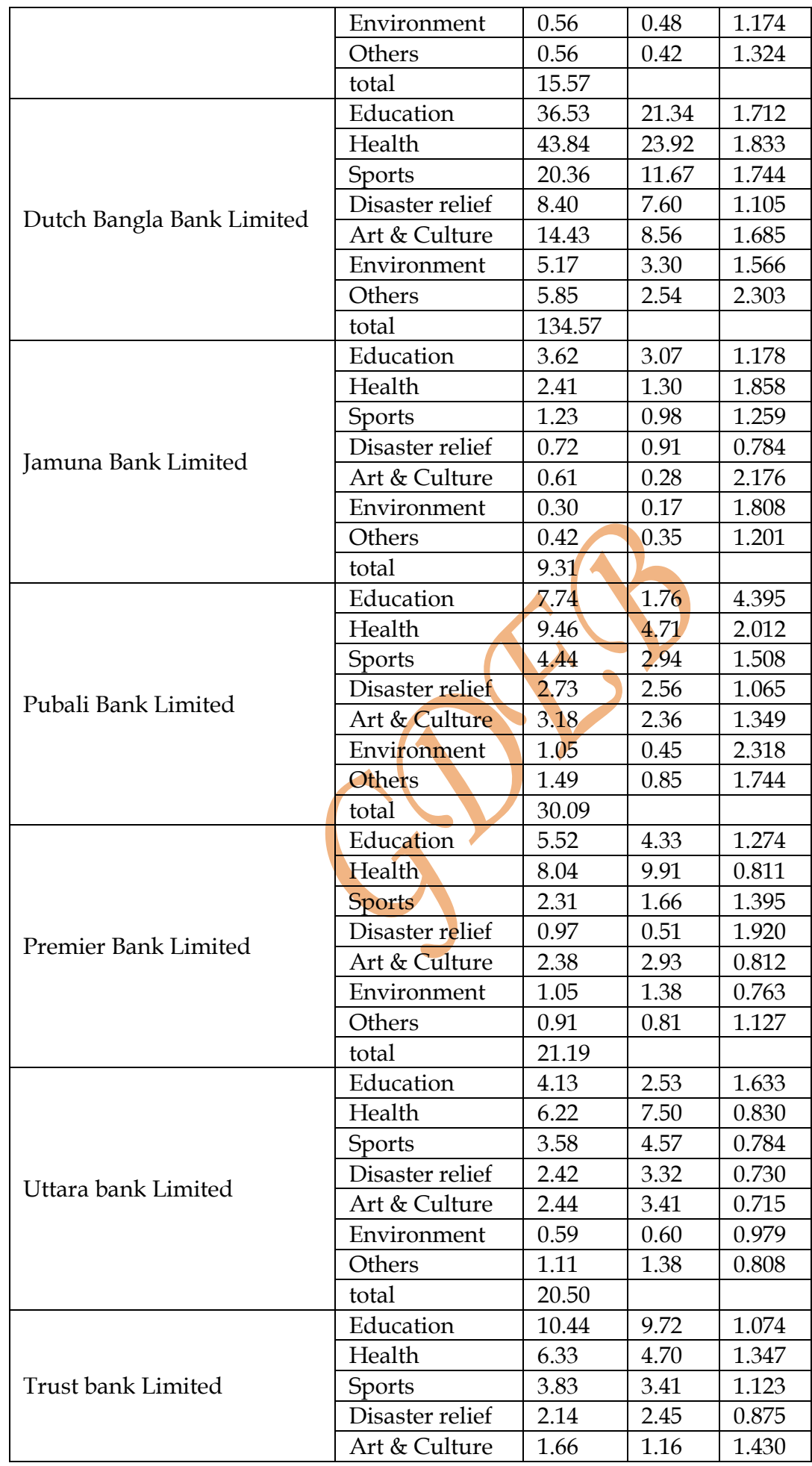




\begin{tabular}{|l|l|l|l|l|}
\hline \multirow{5}{*}{ Mercantile Bank Limited } & Environment & 0.76 & 0.60 & 1.250 \\
\cline { 2 - 5 } & Others & 1.19 & 1.01 & 1.171 \\
\cline { 2 - 5 } & total & 26.34 & & \\
\hline & Education & 8.23 & 7.24 & 1.137 \\
\cline { 2 - 5 } & Health & 12.47 & 16.31 & 0.764 \\
\cline { 2 - 5 } & Sports & 3.50 & 2.85 & 1.226 \\
\cline { 2 - 5 } & Disaster relief & 1.26 & 0.60 & 2.105 \\
\cline { 2 - 5 } & Art \& Culture & 3.70 & 4.82 & 0.769 \\
\cline { 2 - 5 } & Environment & 1.64 & 2.26 & 0.727 \\
\cline { 2 - 5 } & Others & 1.35 & 1.36 & 0.987 \\
\cline { 2 - 5 } & total & 32.15 & & \\
\hline \multirow{5}{*}{ Dhaka Bank Limited } & Education & 7.49 & 5.35 & 1.401 \\
\cline { 2 - 5 } & Health & 6.25 & 1.77 & 3.532 \\
\cline { 2 - 5 } & Sports & 3.51 & 2.28 & 1.539 \\
\cline { 2 - 5 } & Disaster relief & 1.76 & 1.32 & 1.335 \\
\cline { 2 - 5 } & Art \& Culture & 1.94 & 0.91 & 2.125 \\
\cline { 2 - 5 } & Environment & 0.72 & 0.21 & 3.398 \\
\cline { 2 - 5 } & Others & 1.02 & 0.38 & 2.655 \\
\cline { 2 - 5 } & total & 22.69 & & \\
\hline
\end{tabular}

Source: BB Report on CSR in July2011

Table 08: Coefficient of Correlations

\begin{tabular}{|l|l|l|l|l|l|l|l|l|l|}
\hline & & MPS & $\begin{array}{l}\text { Educ } \\
\text { ation }\end{array}$ & Health & Sports & $\begin{array}{l}\text { Disaster } \\
\text { relief }\end{array}$ & $\begin{array}{l}\text { Art and Enviro } \\
\text { culture } \\
\text { nment }\end{array}$ & $\begin{array}{l}\text { Other } \\
\text { s }\end{array}$ \\
\hline Pearson Correlation & MPS & 1.000 & & & & & & & \\
\hline & Education & .356 & 1.000 & & & & & & \\
\hline & Health & .348 & .728 & 1.000 & & & & & \\
\hline & Sports & .260 & .829 & .791 & 1.000 & & & & \\
\hline & Disaster relief & .233 & .315 & .533 & .693 & 1.000 & & & \\
\hline & Art and culture & .301 & .648 & .975 & .838 & .668 & 1.000 & & \\
\hline & Environment & .354 & .717 & .966 & .676 & .351 & .895 & 1.000 & \\
\hline & Others & .357 & .696 & .916 & .886 & .818 & .953 & .811 & 1.000 \\
\hline & MPS & & .012 & .014 & .052 & .074 & .030 & .013 & .012 \\
\hline & Education & .012 & & & & & & & \\
\hline & Health & .014 & .000 & & & & & & \\
\hline & Sports & .052 & .000 & .000 & & & & & \\
\hline & Disaster relief & .074 & .024 & .000 & .000 & & & & \\
\hline & Art and culture & .030 & .000 & .000 & .000 & .000 & & & \\
\hline & Environment & .013 & .000 & .000 & .000 & .013 & .000 & & \\
\hline & Others & .012 & .000 & .000 & .000 & .000 & .000 & .000 &. \\
\hline
\end{tabular}

